\title{
Continuous Antisolvent Crystallization of $\alpha$-Lactose Monohydrate: Impact of Process Parameters, Kinetic Estimation and Dynamic Analysis
}

\author{
Nitin Pawar, Shailesh Agrawal*, Ravi Methekar \\ 1,2,3 Department of Chemical Engineering, Visvesvaraya National Institute of Technology, \\ Nagpur, Maharashtra, India. \\ Email id: shaileshagrawal@che.vnit.ac.in ${ }^{2 *}$
}

\section{SUPPLEMENTARY INFORMATION (S1)}

\section{Dissolved lactose measurement}

Refractometer (Refractive index) is a popular technique for concentration measurement of sugars. The ' ${ }^{\circ}$ Brix' ' unit represents the strength of the solution in terms of mass of sucrose per 100 gram of the solution. To use it for lactose concentration measurement, a relationship with known lactose concentration vs. ${ }^{\circ}$ Brix was determined (as shown in Figure S1).

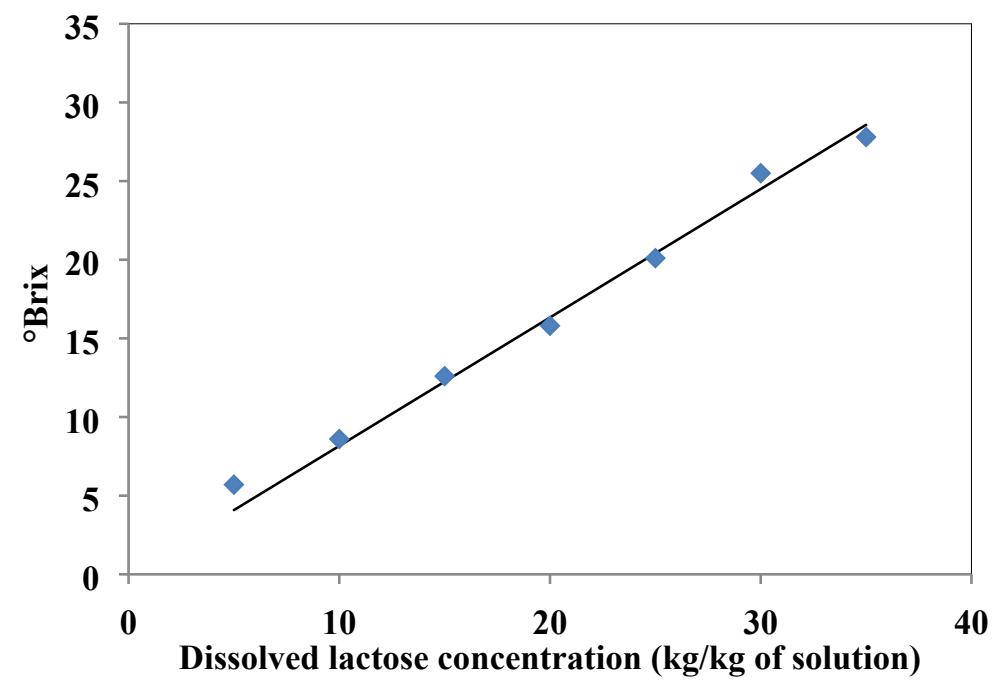

Figure S1. Relationship between ${ }^{\circ}$ Brix (Refractometer) and the dissolved lactose concentration (gravimetric) 
The trials in this study involve the use of ethanol as an anti-solvent. Since ethanol's refractive index is higher (1.361) than water (1.333), a sugar solution in presence of alcohol will give a higher reading than the actual solids. Thus, another relationship between ${ }^{\circ}$ Brix reading at different ethanol concentrations $(\% \mathrm{v} / \mathrm{v})$ was plotted as shown in Figure S2.

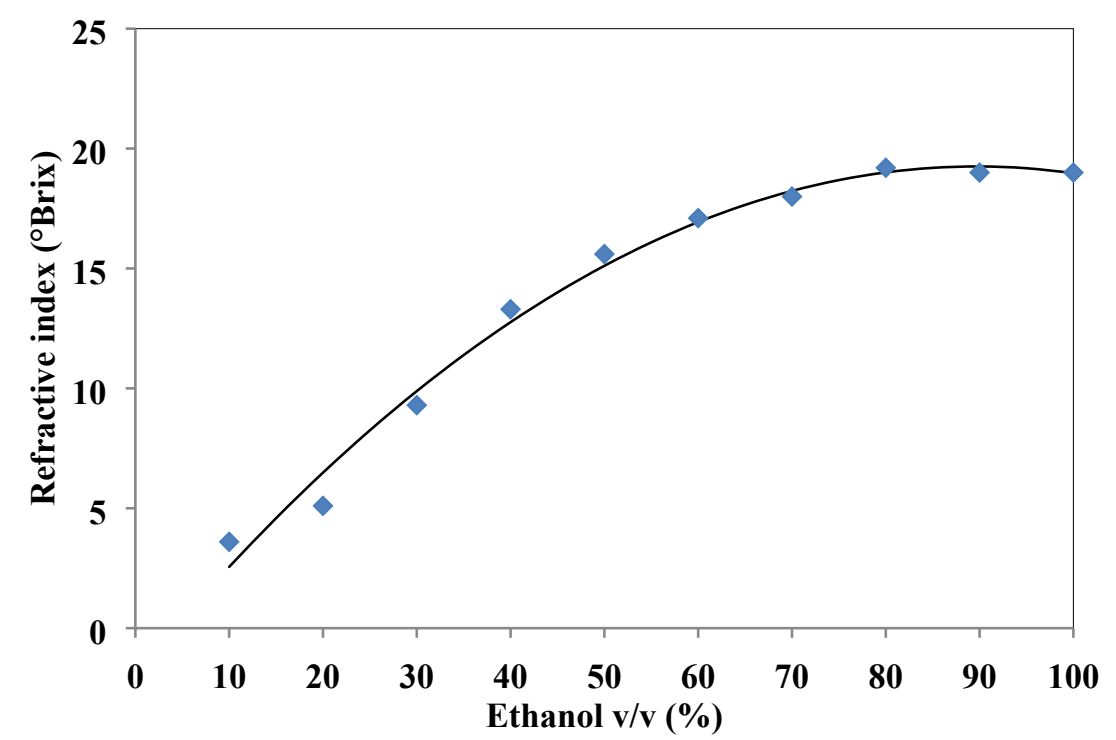

Figure S2. Relationship between ${ }^{\circ}$ Brix and ethanol concentration

The actual concentration of lactose in presence of ethanol can be measured by subtracting the contribution of ethanol from the total ${ }^{\circ}$ Brix reading. This was confirmed by analysing the samples taken at different time intervals (containing ethanol, water, crystallized lactose and dissolved lactose) during the trials. The crystals were removed by filtering them through 0.45 $\mu \mathrm{m}$ syringe filter. The filtrate was then analyzed for dissolved lactose concentration by gravimetric method (drying in an oven at $110^{\circ} \mathrm{C}$ for $6 \mathrm{hrs}$ ) and also by a refractometer ( ${ }^{\circ}$ Brix). The actual lactose concentration from ${ }^{\circ}$ Brix measurement was obtained by subtracting the contribution of ethanol and then adjusting the ${ }^{\circ}$ Brix reading for lactose using the standard curve obtained previously. The $\% \mathrm{v} / \mathrm{v}$ concentration of ethanol was calculated by the flow rate of ethanol addition. The lactose measured by refractometer matched very well 
with that measured by gravimetric analysis (Figure S3). From here, all the dissolved lactose concentration was determined using the refractometer.

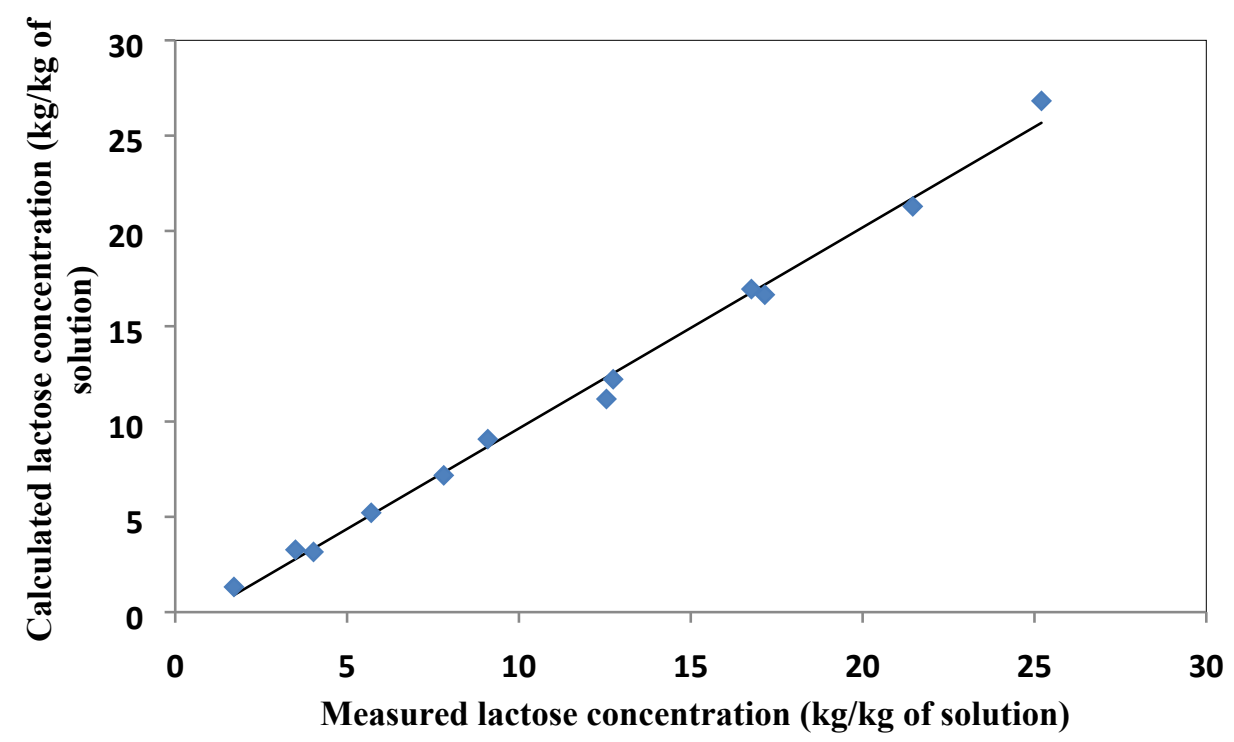

Figure S3. Relationship between the measured dissolved lactose (gravimetric) and calculated lactose concentration (refractometer) in presence of ethanol.

\section{$\underline{\text { SUPPLEMENTARY INFORMATION (S2) }}$}

\section{Effect of initial lactose concentration}

The crystal micrographs (Figure S4), as well as XRD pattern (Figure S5) of crystal recovered at the end of trial (7200 s), showed the formation of $\alpha$-lactose monohydrate crystals.

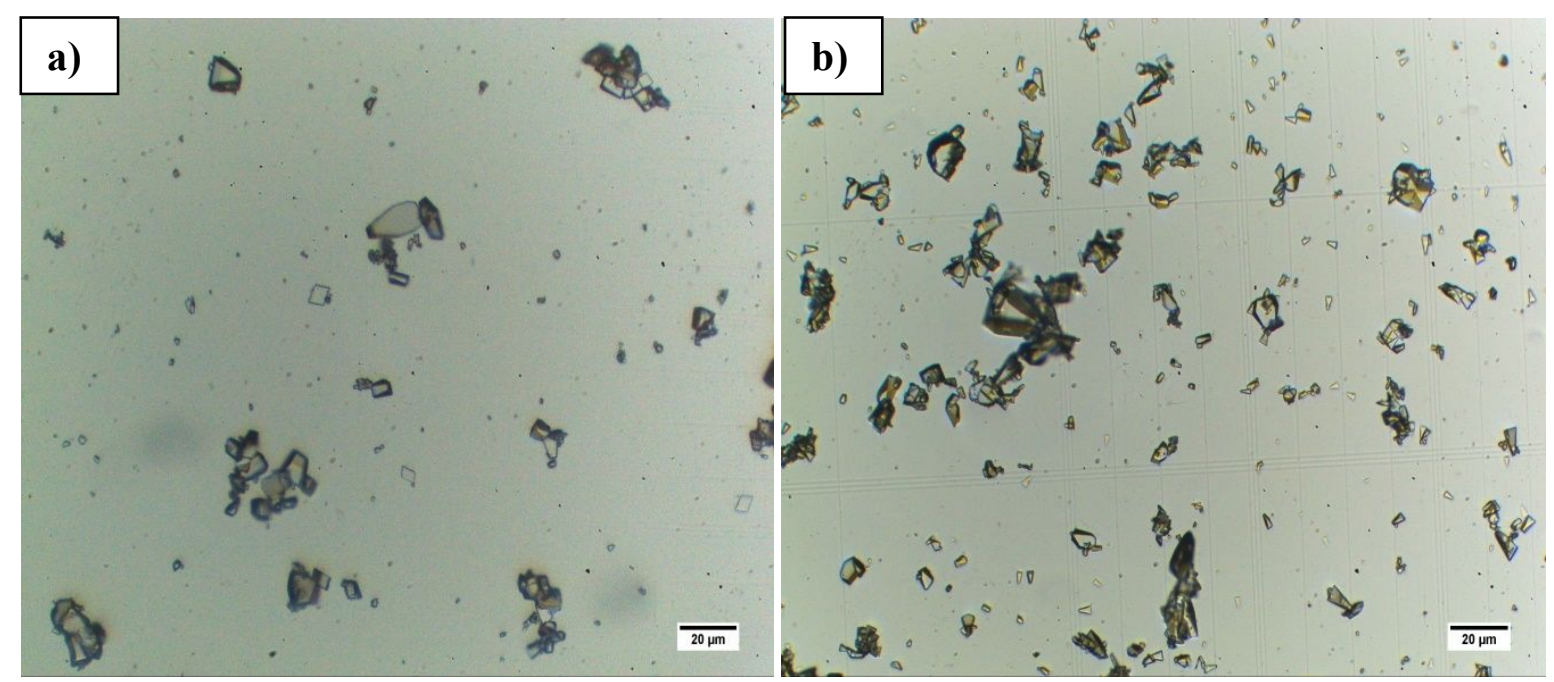




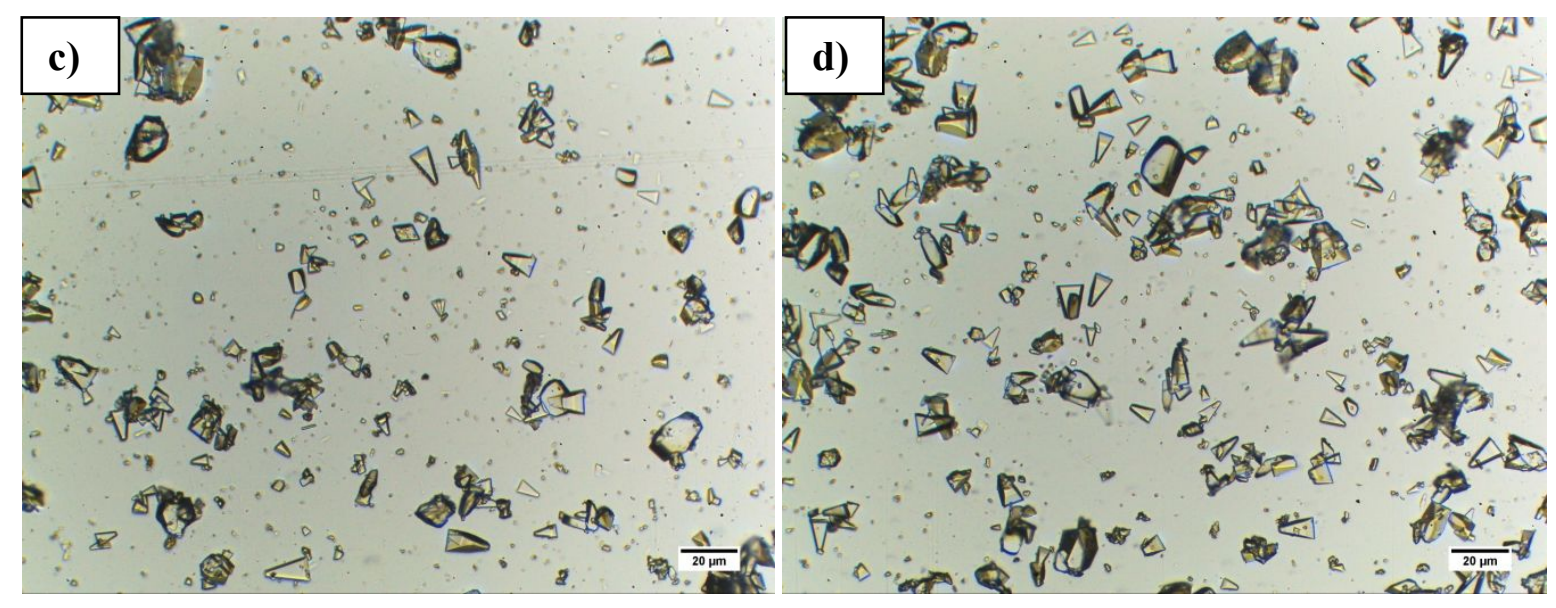

Figure S4. Photographs of lactose crystals recovered at the end of trial for a) 0.20 b) 0.25 c) 0.30 and d) $0.37 \mathrm{~kg} / \mathrm{kg}$ of lactose concentration. Flow rate for both lactose solution and ethanol was $0.25 \mathrm{~mL} / \mathrm{s}$ and residence time was $\tau=900 \mathrm{~s}$.

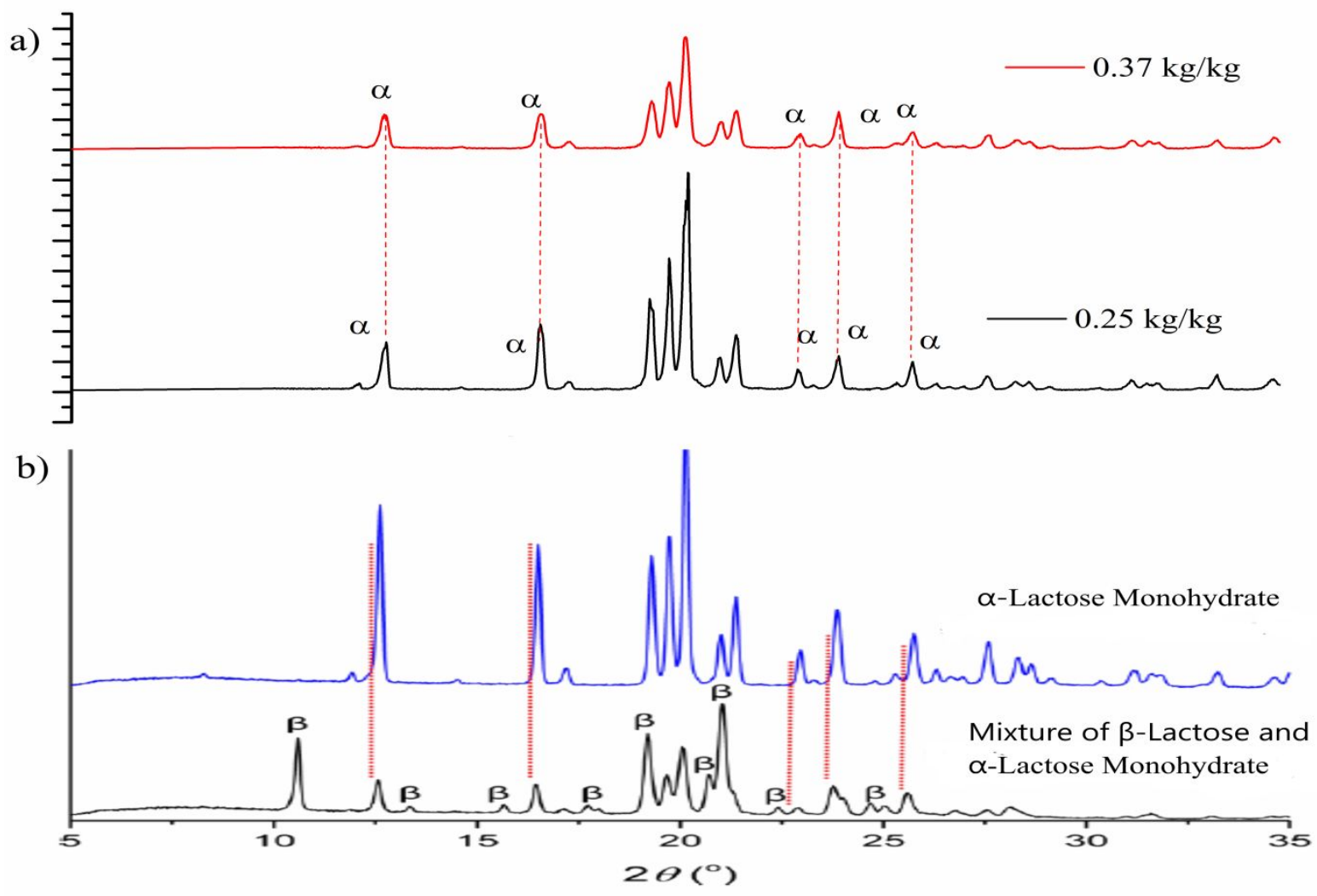

Figure S5. (a) XRD analysis of lactose samples recovered at the end of trial s for $0.25 \mathrm{~kg} / \mathrm{kg}$ and $0.37 \mathrm{~kg} / \mathrm{kg}$ of solution.Flow rate for both lactose solution and ethanol was $0.25 \mathrm{~mL} / \mathrm{s}$ and residence time was $\tau=900$ s. (b)The PXRD patterns as reported by MacFhionnghaile et al. ${ }^{1}$ 


\section{Effect of residence time}

The micrographs (Figure S6) and the XRD pattern (Figure S7) of the crystals obtained at the end of trial confirm the formation of only $\alpha$-lactose monohydrate.

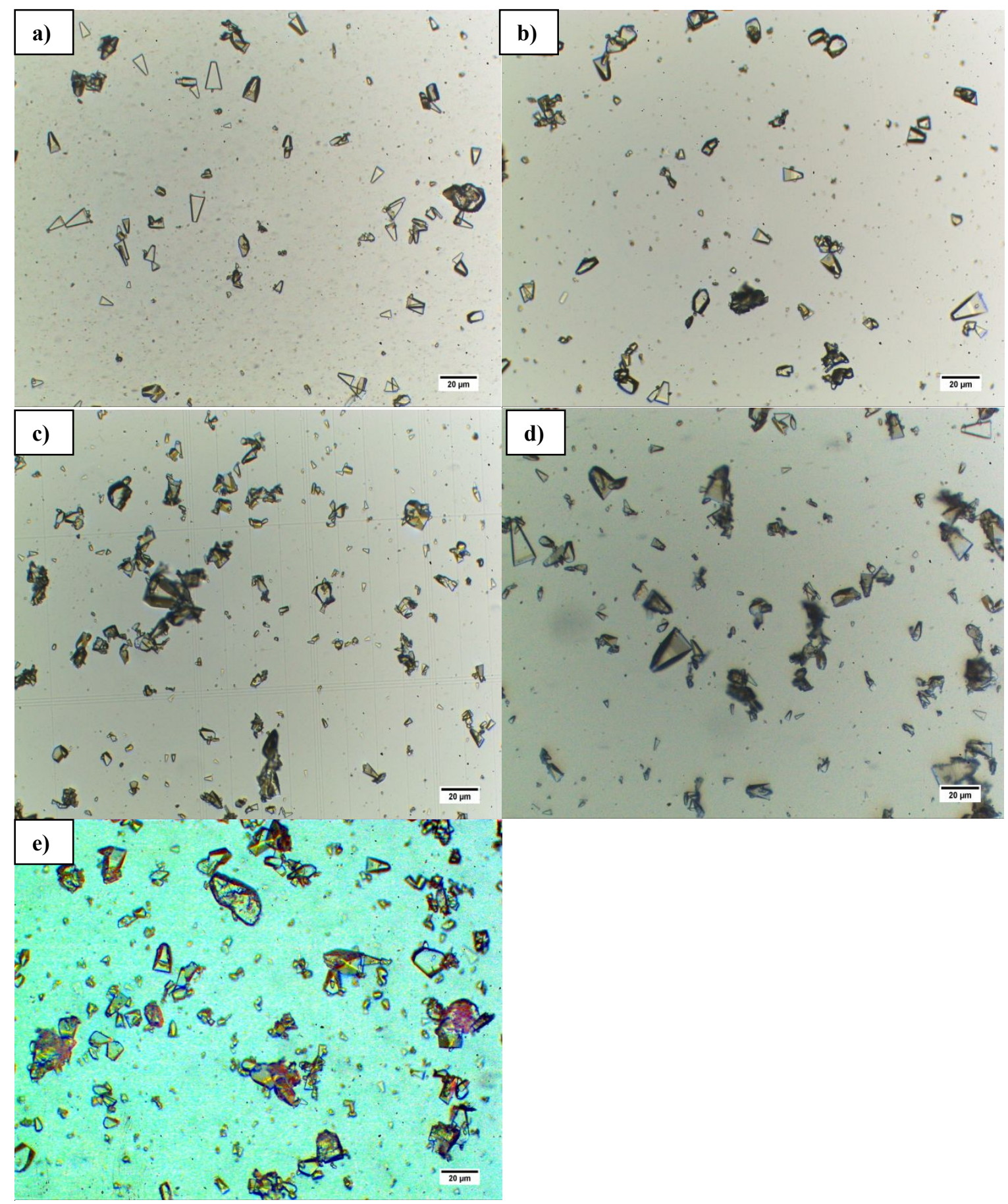

Figure S6. Photographs of lactose crystals recovered at the end of crystallization time i.e. a) $4200 \mathrm{~s}, \tau=450 \mathrm{~s}$ b) $5400 \mathrm{~s}, \tau=600 \mathrm{~s} \mathrm{c}) 7200 \mathrm{~s}, \tau=900 \mathrm{~s}$ d) $10800 \mathrm{~s}, \tau=1500 \mathrm{~s}$ e) 12600 
$\mathrm{s}, \tau=2100 \mathrm{~s}$. Initial lactose concentration was $0.25 \mathrm{~kg} / \mathrm{kg}$. Ratio of addition rate antisolvent to lactose solution was maintained as 1:1 for all residence times.

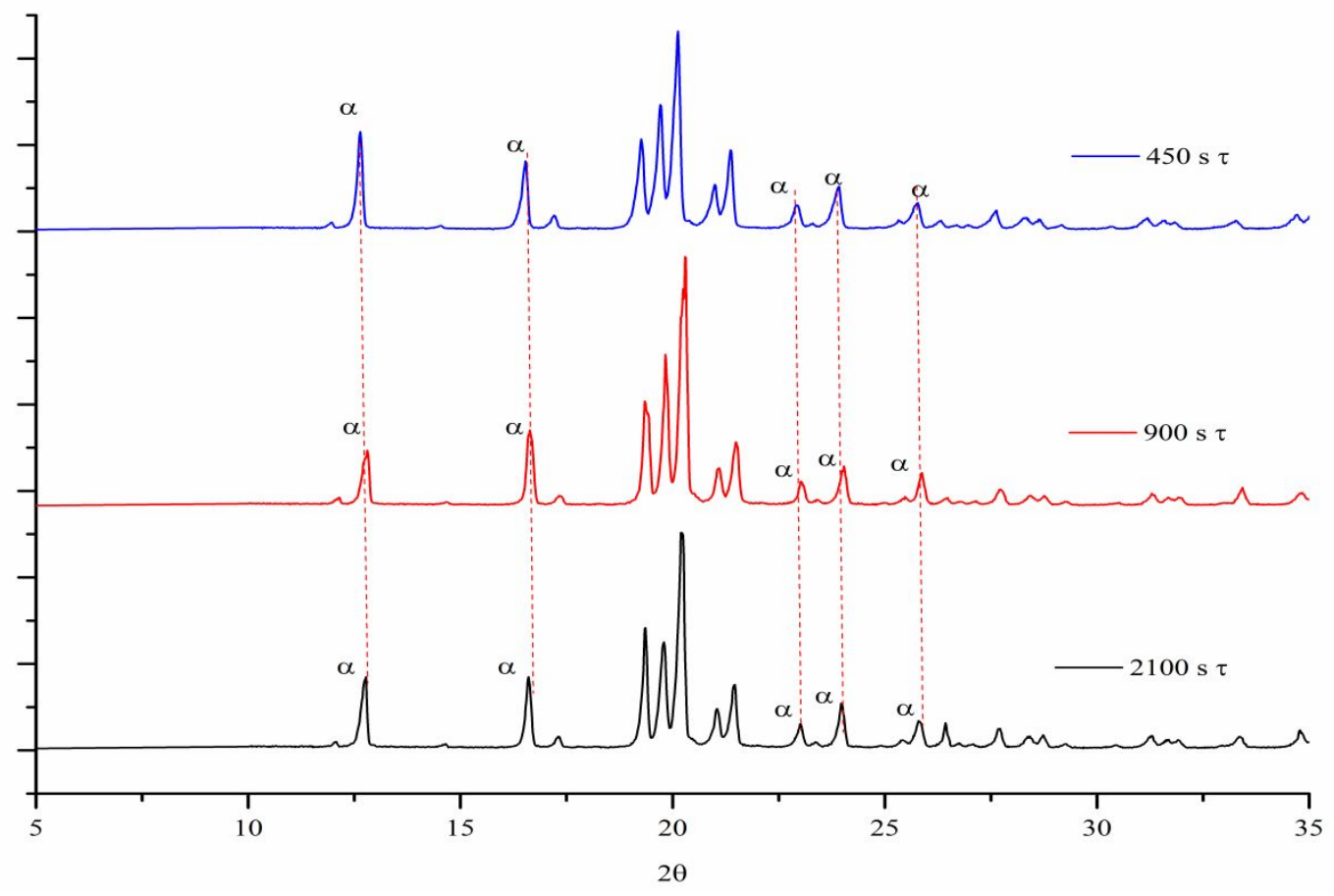

Figure S7. XRD analysis of lactose samples recovered at the end of crystallization time for different residence times a) $450 \mathrm{~s} \mathrm{b)} 900 \mathrm{~s}$ and c) $2100 \mathrm{~s}$. Initial lactose concentration was $0.25 \mathrm{~kg} / \mathrm{kg}$. Ratio of addition rate antisolvent to lactose solution was maintained as 1:1 for all residence times.

\section{Effect of impurities}

Figure S8 shows the micrographs of lactose crystals recovered at different WPC concentration i.e. $0.1,0.25$ and $0.5 \% \mathrm{~kg} / \mathrm{kg}$ of solution. The figure shows the formation of polyhedral shape (plate or tomahawk shaped) lactose crystals throughout the trial. 

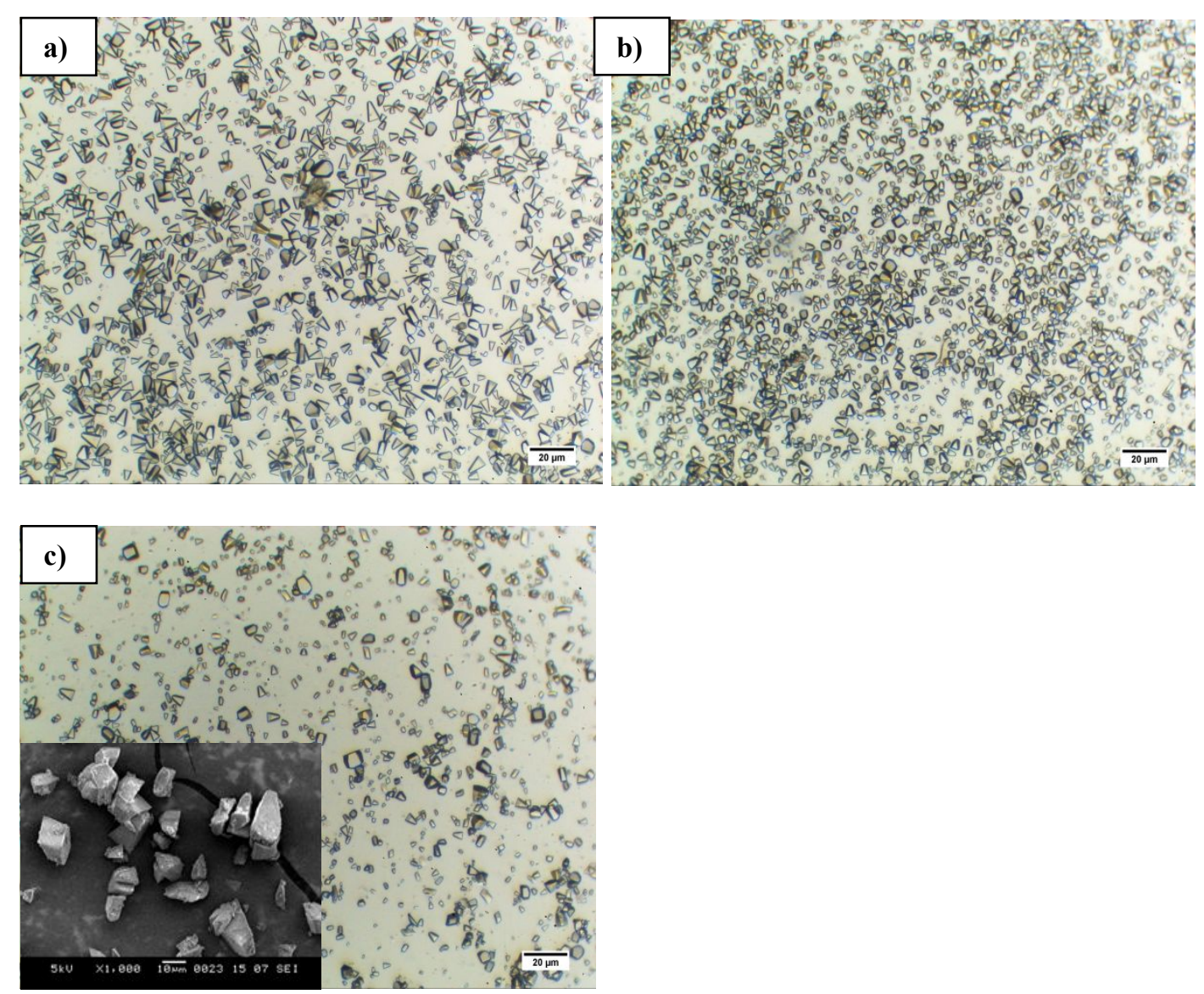

Figure S8. Photographs of lactose crystals recovered at the end of crystallization for a) $0.1 \%$ WPC b) $0.25 \%$ WPC c) $0.5 \%$ WPC. Initial lactose concentration was $0.25 \mathrm{~kg} / \mathrm{kg}$. The flow rate was $0.25 \mathrm{~mL} / \mathrm{s}$ for both lactose and ethanol solution and residence time was $\tau=900 \mathrm{~s}$. For $0.5 \% \mathrm{WPC}$ the corresponding SEM image is shown in the inset.

Figure S9 shows the FTIR analysis of pure lactose, WPC and lactose sample recovered at the end of crystallization for $0.5 \%$ WPC. The pure lactose sample and the lactose recovered at $0.5 \%$ WPC have very similar spectra with absence of peak for the WPC at 1590 and 1650 $\mathrm{cm}^{-1}$. 


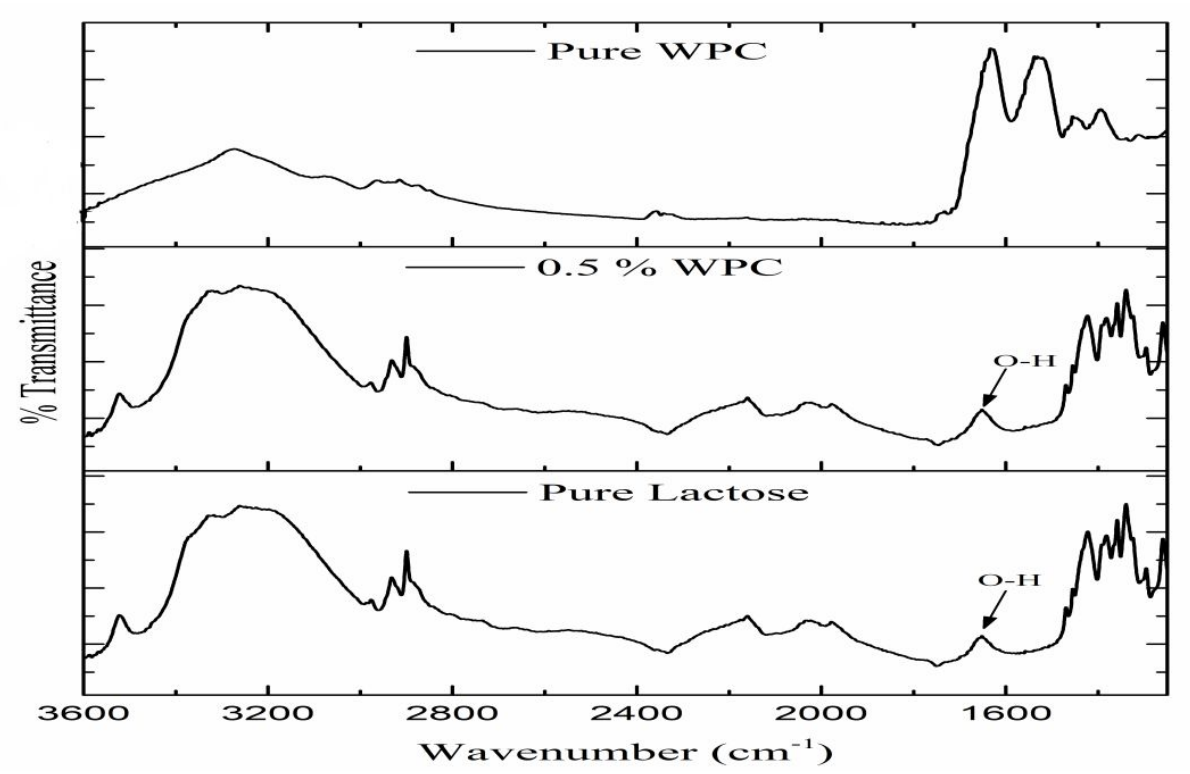

Figure S9. FTIR spectrum of pure lactose, WPC and lactose recovered for $0.5 \%$ WPC. The initial lactose concentration was $0.25 \mathrm{~kg} / \mathrm{kg}$. The flow rate was $0.25 \mathrm{~mL} / \mathrm{s}$ for both lactose and ethanol solution and residence time was $\tau=900 \mathrm{~s}$

\section{Effect of recycle}

The micrographs (Figure S10) and PXRD patterns (Figure S11) shows the formation of only $\alpha$-lactose monohydrate crystals as discussed previously.

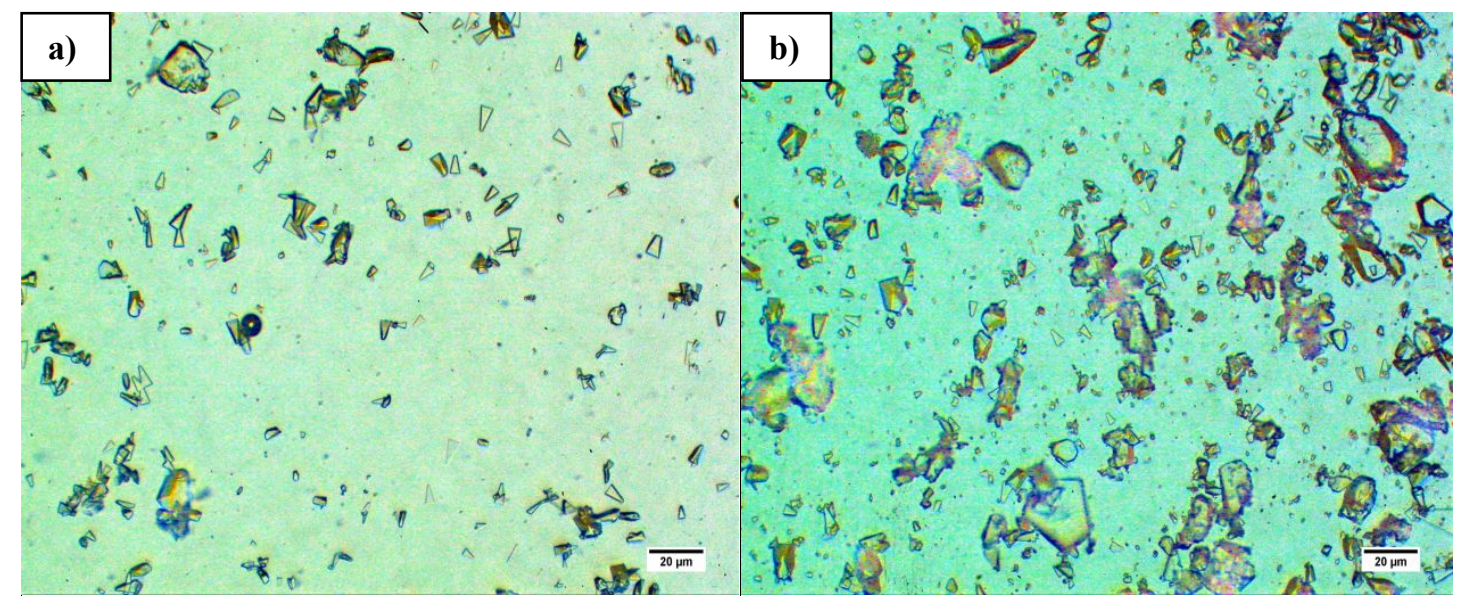

Figure S10. The micrographs of lactose crystals recovered at the end of crystallization time

a) Without fines recycle b) With Fine recycle. Initial lactose concentration was $0.25 \mathrm{~kg} / \mathrm{kg}$. 
The flow was $0.125 \mathrm{~mL} / \mathrm{s}$ for both lactose solution and antisolvent. Recycle ratio was 0.5 and residence time was $\tau=900 \mathrm{~s}$.

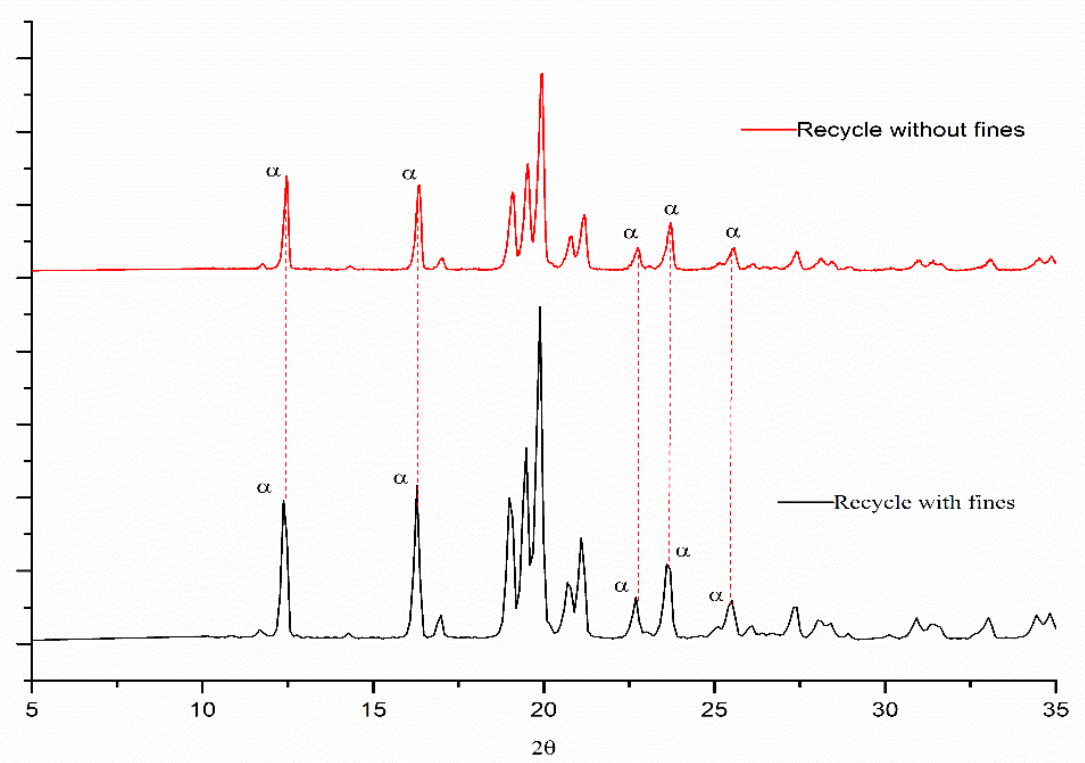

Figure S11. XRD analysis of lactose samples recovered at the end of crystallization time for a) Recycle with fines b) Recycle without fines. Initial lactose concentration was $0.25 \mathrm{~kg} / \mathrm{kg}$. The flow was $0.125 \mathrm{~mL} / \mathrm{s}$ for both lactose solution and antisolvent. Recycle ratio was 0.5 and residence time was $\tau=900 \mathrm{~s}$.

\section{Effect of anti-solvent addition rate}

Figure S12 shows the micrographs of lactose crystals recovered at a different time interval for different antisolvent addition rates.

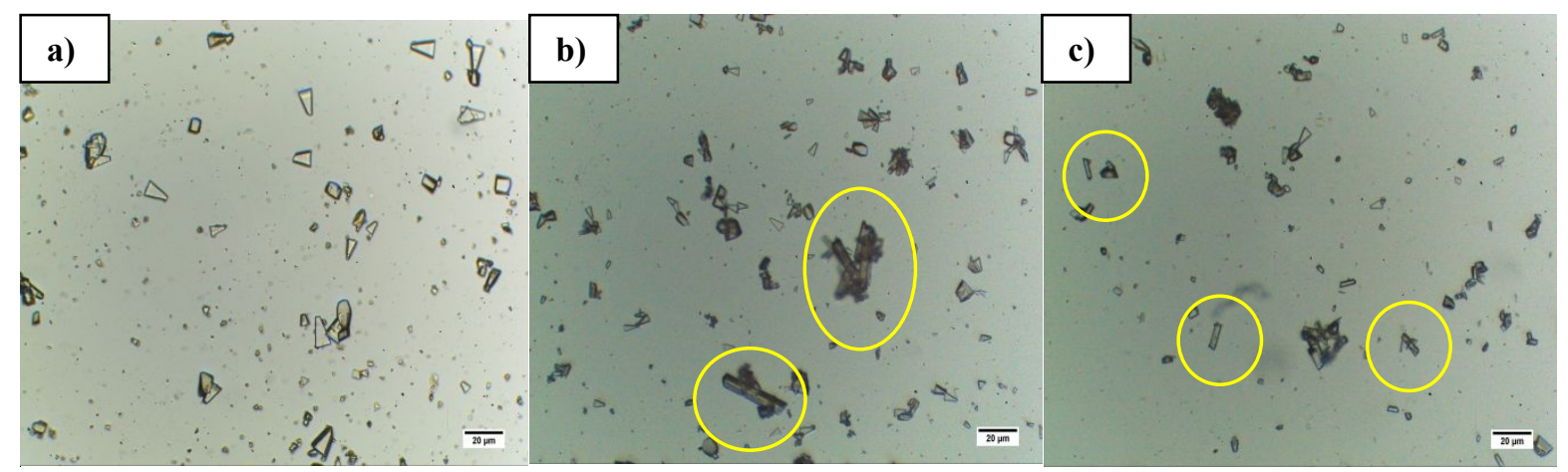


Figure S12. Micrographs of the crystals recovered for different antisolvent addition rate (a) $0.25 \mathrm{~mL} / \mathrm{s}$ at $1800 \mathrm{~s}$ (b) $0.375 \mathrm{~mL} / \mathrm{s}$ at $1200 \mathrm{~s}$ and (c) $0.5 \mathrm{~mL} / \mathrm{s}$ at $600 \mathrm{~s}$. Initial lactose concentration was $0.25 \mathrm{~kg} / \mathrm{kg}$. The flow rate of lactose solution was $0.25 \mathrm{~mL} / \mathrm{s}$ and residence time were 900, 720 and $600 \mathrm{~s}$ for respective antisolvent flow rates. The rounded portion in the image consists of a rod or needle-shaped $\beta$-lactose crystals.

\section{SUPPLEMENTARY INFORMATION (S3)}

\section{MATHEMATICAL MODELLING of CONTINUOUS ANTISOLVENT CRYSTALLIZATION}

The general population balance equation with assumptions of insignificant breakage/agglomeration and size independent growth is represented by equation (S1) ${ }^{2}$

$\frac{\partial \mathrm{n}(\mathrm{L}, \mathrm{t})}{\partial \mathrm{t}}=-G \frac{\partial \mathrm{n}(\mathrm{L}, \mathrm{t})}{\partial \mathrm{L}}-\frac{n(L, t)}{\tau}$

The population balance equation (PBE) (equation S1) was solved by using the Method of Moments (MOMs). The MOMs converts the PBE into a set of ordinary differential equations (ODEs) that can be solved together with the mass balance equations. The different moments have some special significance regarding crystal population such as number of crystals (zeroth moment $\left.\left(m_{0}\right)\right)$, length of crystals (first moment $\left(m_{1}\right)$ ), surface area of crystals (second moment $\left.\left(m_{2}\right)\right)$ and the volume of crystals (third moment $\left.\left(m_{3}\right)\right)$.

The $\mathrm{i}^{\text {th }}$ moment is represented as ${ }^{3}$

$m_{i}=\int_{0}^{\infty} L^{i} n(L) d L$

From equation S2, the zero moment derivative is represented as

$\frac{\mathrm{dm}_{0}}{\mathrm{dt}}=\mathrm{B}-\frac{\mathrm{m}_{0}}{\tau}$

The first moment derivative as 
$\frac{\mathrm{dm}_{1}}{\mathrm{dt}}=\mathrm{G} m_{0}-\frac{\mathrm{m}_{1}}{\tau}$

The second moment derivative as

$\frac{\mathrm{dm}_{2}}{\mathrm{dt}}=2 \mathrm{G} m_{1}-\frac{\mathrm{m}_{2}}{\tau}$

The third moment derivative as

$\frac{\mathrm{dm}_{3}}{\mathrm{dt}}=3 \mathrm{G} m_{2}-\frac{\mathrm{m}_{3}}{\tau}$

The fourth moment derivative as

$\frac{\mathrm{dm}_{4}}{\mathrm{dt}}=4 \mathrm{G} m_{3}-\frac{\mathrm{m}_{4}}{\tau}$

In continuous crystallization, during start-up, the process is first operated in a semi-batch (or fed-batch) mode and once the overflow starts, it shifts into continuous mode. The developed model thus should capture these two distinct modes i.e. semi-batch and continuous. For a semi-batch process, with no outflow $\tau=\infty$, the second term on the right-hand side in the moment equations becomes zero. During continuous operation, the specific residence time $(\tau)$ can be used.

The mathematical model incorporates two mass balance equations, namely, total mass balance and overall solute balance. The rate of change of total mass balance of the crystallizer is given by

$\frac{d M}{d t}=Q_{f} \rho_{f}+Q_{e} \rho_{e}-Q_{o} \rho_{s} x-Q_{o} \rho_{s} \varphi-0.95 Q_{o} \rho_{c}(1-\varphi)$

where the first and second term denotes the mass of lactose solution and ethanol fed to the system whereas third, fourth and fifth term represent the mass of ethanol, dissolved lactose and crystalline lactose leaving the system and $x$ is the mass fraction of antisolvent in the slurry.

The overall solute (lactose) balance is given by

$\frac{d}{d t}[\mathrm{M} \varphi \mathrm{C}]+\frac{d}{d t}[0.95 \mathrm{M}(1-\varphi)]=Q_{f} \rho_{f} C_{f}-Q_{o} \rho_{s} \varphi C-0.95 Q_{o} \rho_{c}(1-\varphi)$ 
where the term on the left-hand side of equation S9 represents the accumulation of dissolved and crystalline lactose in the crystallizer, whereas, the terms on right-hand side denotes the initial mass of dissolved solute entering the system, the mass of the dissolved solute and crystals formed in the crystallizer due to nucleation and/or growth in the solution leaving the crystallizer in continuous mode. The crystalline lactose term is multiplied by 0.95 $\left(\mathrm{MW}_{\alpha \mathrm{L}} / \mathrm{MW}_{\alpha \mathrm{LH}}=342 / 360=0.95\right)^{4}$ to account for the water of crystallization present in the crystal.

Equation S9 on simplification

$\frac{d C}{d t}=\frac{Q_{f} \rho_{f} C_{f}}{M \varphi}-\frac{C}{\tau}-\frac{0.95 \rho_{c}(1-\varphi)}{\tau \rho_{s}}-\frac{M[C-0.95] \frac{d \varphi}{d t}}{M \varphi}-\frac{[C \varphi+0.95(1-\varphi)] \frac{d M}{d t}}{M \varphi}$

where $\tau=\frac{M}{Q_{o} \rho_{s}}$

Mathematical model with recycle: The provision for recycle required addition of a collection tank in which the outflow from the crystallizer is collected for $1 \mathrm{~h}$ before being recycled at a given ratio. The overall mass balance across the collection tank is represented as

$\frac{d M_{t}}{d t}=Q_{o} \varphi \rho_{s}+0.95 Q_{o}(1-\varphi) \rho_{c}-Q_{r} \varphi_{r} \rho_{r}-0.95 Q_{r}\left(1-\varphi_{r}\right) \rho_{c}-Q_{o u t} \varphi_{t} \rho_{t}-$ $0.95 Q_{\text {out }}\left(1-\varphi_{t}\right) \rho_{c}$

Where, the first and second terms are the liquid and crystal mass entering the collection tank from the crystallizer. The third and fifth term denotes the mass of liquid leaving the collection tank as the recycle stream and outflow, respectively. The fourth and sixth term denotes the crystal mass leaving the collection tank as the recycle stream and outflow. For recycle without fines i.e. the crystals are separated via filtration before entering the collection tank, $\varphi_{r}=\varphi=\varphi_{t}=1$, and hence the above equation reduces to

$$
\frac{d M_{t}}{d t}=Q_{o} \varphi \rho_{s}-Q_{r} \varphi_{r} \rho_{r}-Q_{o u t} \varphi_{t} \rho_{t}
$$


For recycle with fines, $\varphi_{r}{ }^{5}$ was calculated experimentally and assumed to be constant, $\varphi$ is known from model (equation S26) and $\varphi_{t}$ was calculated from the crystal mass balance across the collection tank :

$Q_{o} \varphi \rho_{c}=Q_{r} \varphi_{r} \rho_{c}+Q_{o u t} \varphi_{t} \rho_{c}$

Solute balance across the tank is given as

$\frac{d C_{t}}{d t}=\frac{Q_{o} \rho_{s} C}{M \varphi}+\frac{0.95 Q_{o}(1-\varphi) \rho_{c}}{M \varphi}-\frac{Q_{\text {out }} \rho_{t} C_{t}}{M \varphi}-\frac{0.95 Q_{\text {out }}\left(1-\varphi_{t}\right) \rho_{c}}{M \varphi}-\frac{Q_{r} \rho_{r} C_{t}}{M \varphi}-\frac{0.95 Q_{r}\left(1-\varphi_{r}\right) \rho_{c}}{M \varphi}-\frac{M_{t}[C-0.95] \frac{d \varphi}{d t}}{M \varphi}-$ $\frac{[C \varphi+0.95(1-\varphi)] \frac{d M_{t}}{d t}}{M \varphi}$

For a model with recycle stream, equation S8 and S10 are modified as:

$\frac{d M}{d t}=Q_{f} \rho_{f}+Q_{e} \rho_{e}+Q_{r} \varphi_{r} \rho_{r}+0.95 Q_{r}\left(1-\varphi_{r}\right) \rho_{c}-Q_{o} \rho_{s} x-Q_{o} \rho_{s} \varphi C-0.95 Q_{o} \rho_{c}(1-\varphi)$

$$
\begin{aligned}
& \frac{d C}{d t}=\frac{Q_{f} \rho_{f} C_{f}}{M \varphi}+\frac{Q_{r} \rho_{r} C_{t}}{M \varphi}+\frac{0.95 Q_{r} \rho_{c}\left(1-\varphi_{r}\right)}{M \varphi}-\frac{C}{\tau}-\frac{0.95 \rho_{c}(1-\varphi)}{\tau \rho_{s}}-\frac{M[C-0.95] \frac{d \varphi}{d t}}{M \varphi}- \\
& \frac{[C \varphi+0.95(1-\varphi)] \frac{d M}{d t}}{M \varphi}
\end{aligned}
$$

Lactose crystallization kinetics and solubility: The primary nucleation rate $(B)$ kinetics is expressed as

$\mathrm{B}=\mathrm{k}_{\mathrm{b}}(\Delta \mathrm{C})^{\mathrm{b}}$

where $\Delta C$ the concentration driving force given by $\left(C_{\alpha}-C_{\alpha e}\right)$. Growth rate $(G)(\mathrm{m} / \mathrm{s})$ is given by the following equation

$\mathrm{G}=\mathrm{k}_{\mathrm{g}}(\Delta \mathrm{C})^{\mathrm{g}}$

The total lactose concentration $(C)$ is the sum of $\alpha$ - and $\beta$ - lactose concentrations ${ }^{6}$,

$$
\mathrm{C}=\mathrm{C}_{\alpha}+\mathrm{C}_{\beta}
$$

The equilibrium mutarotation rate constant $\left(K_{m}\right)$ is defined as

$$
\mathrm{K}_{\mathrm{m}}=\mathrm{C}_{\beta} / \mathrm{C}_{\alpha}
$$

$\mathrm{K}_{\mathrm{m}}$ is represented as ${ }^{7}$ 
$\mathrm{K}_{\mathrm{m}}=-0.0024 \mathrm{~T}+1.6353$

The $K_{m}$ of value 1.5393 (at $40^{\circ} \mathrm{C}$ ) is used in this study. The $\alpha$-lactose monohydrate concentration can be calculated from the total lactose concentration,

$\mathrm{C}_{\alpha}=\frac{1}{\left(1+\mathrm{K}_{\mathrm{m}}\right)}$

The equilibrium concentration of $\alpha$-lactose monohydrate concentration can be calculated by

$\mathrm{C}_{\alpha \mathrm{e}}=\frac{\left(C_{e}-F * K_{m} *\left(C-C_{e}\right)\right)}{1+K_{m}}$

Where $F$ is the temperature dependent correction factor and represented as.

$\mathrm{F}=0.0187 e^{0.0236 T}$

Equilibrium concentration $\left(C_{e}\right)$ of the lactose in ethanol-water solution at $40{ }^{\circ} \mathrm{C}$ was taken from Machado et al. ${ }^{8}$

$\mathrm{Ce}=-0.4948 \mathrm{x}^{4}+0.9069 \mathrm{x}^{3}-0.1292 \mathrm{x}^{2}-0.5362 \mathrm{x}+0.2527$

Slurry properties: average crystal size, crystal content, and density: The slurry voidage can be determined as

$\varphi=1-\rho_{c} m_{3}$

where $m_{3}$ in the above equation is the third moment, represents the total volume of crystals present in the slurry. For recycle without fines, $m_{3}=0$.

Differentiating the above equation gives

$\frac{d \varphi}{d t}=-\rho_{c} \frac{d m_{3}}{d t}$

The crystal content $C_{c}[\mathrm{~kg} / \mathrm{kg}$ of solution $]$ of the slurry is calculated as

$\mathrm{C}_{\mathrm{c}}=\rho_{\mathrm{c}} \mathrm{m}_{3}$

Total solids of the slurry can be determined as ${ }^{9}$

$\mathrm{TS}=\varphi \mathrm{C}+0.95 C_{c}$ 
A study on solution density reveals that the density of the solution is independent of the state of solute (dissolved or crystalline), so the relation between dissolved solute and the solution density can be used to represent the total solids present in the slurry ${ }^{9}$.

$\rho_{s l}=983.2 e^{0.0042(T S)}$

The density of slurry, can be then calculated as:

$\frac{1}{\rho_{s}}=\frac{x}{\rho_{e}}+\frac{(1-x)}{\rho_{s l}}$

The values of all the operational variables studied and the model parameters used in the simulation are reported in Table S1.

Table S1. System properties and crystallization operating parameters for the base case simulations

\begin{tabular}{lll}
\hline Variable & Value & Units \\
\hline Crystallizer volume & 450 & $\mathrm{~mL}$ \\
Crystallization Temperature $(T)$ & 40 & ${ }^{\circ} \mathrm{C}$ \\
Feed Concentration $\left(C_{f}\right)$ & 0.25 & $\mathrm{~kg} / \mathrm{kg}$ of solution \\
Feed Flow rate $\left(Q_{f}\right)$ & 0.25 & $\mathrm{~mL} / \mathrm{s}$ \\
Antisolvent addition rate $\left(Q_{e}\right)$ & 0.25 & $\mathrm{~mL} / \mathrm{s}$ \\
Outlet Flow rate $\left(Q_{o}\right)$ & 0.5 & $\mathrm{~mL} / \mathrm{s}$ \\
Recycle Flow rate $\left(Q_{r}\right)$ & 0.25 & $\mathrm{~mL} / \mathrm{s}$ \\
Outlet Flow rate of tank $\left(Q_{o u t}\right)$ & 0.25 & $\mathrm{~mL} / \mathrm{s}$ \\
Density of lactose solution $\left(\rho_{f}\right)$ & 1092 & $\mathrm{~kg} / \mathrm{m}^{3}$ \\
Density of lactose $\left(\rho_{c}\right)$ & 1545 & $\mathrm{~kg} / \mathrm{m}^{3}$ \\
Density of antisolvent $\left(\rho_{e}\right)$ & 793 & $\mathrm{~kg} / \mathrm{m}^{3}$ \\
Density of solution at equilibrium & 898 & $\mathrm{~kg} / \mathrm{m}^{3}$ \\
$\left(\rho_{\text {eq }}\right)$ at constant $(x)$ and $40{ }^{\circ} \mathrm{C}$ & & \\
Antisolvent mass fraction $(x)$ & 0.44 & $\mathrm{~kg} / \mathrm{kg}$ of slurry \\
Voidage of slurry $(\varphi)$ & 0.911 & $\mathrm{Dimensionless}$ \\
Nucleation order $(b)$ & 0.15 & $(\mathrm{~kg}$ of solution $) /(\mathrm{kg}$ of slurry) \\
Growth order $(g)$ & 1.65 & $\mathrm{Dimensionless}$ \\
Mutarotation rate constant $\left(K_{m}\right)$ & 1.54 & $\mathrm{Dimensionless}$ \\
\hline
\end{tabular}


factor $(F)$

\section{SUPPLEMENTARY INFORMATION (S4)}

\section{Effect of initial lactose concentration}

Figure S13 shows the evolution of average crystal size and residual lactose concentration with time at initial lactose concentration of $0.20,0.25,0.30$ and $0.37 \mathrm{~kg} / \mathrm{kg}$ of solution.
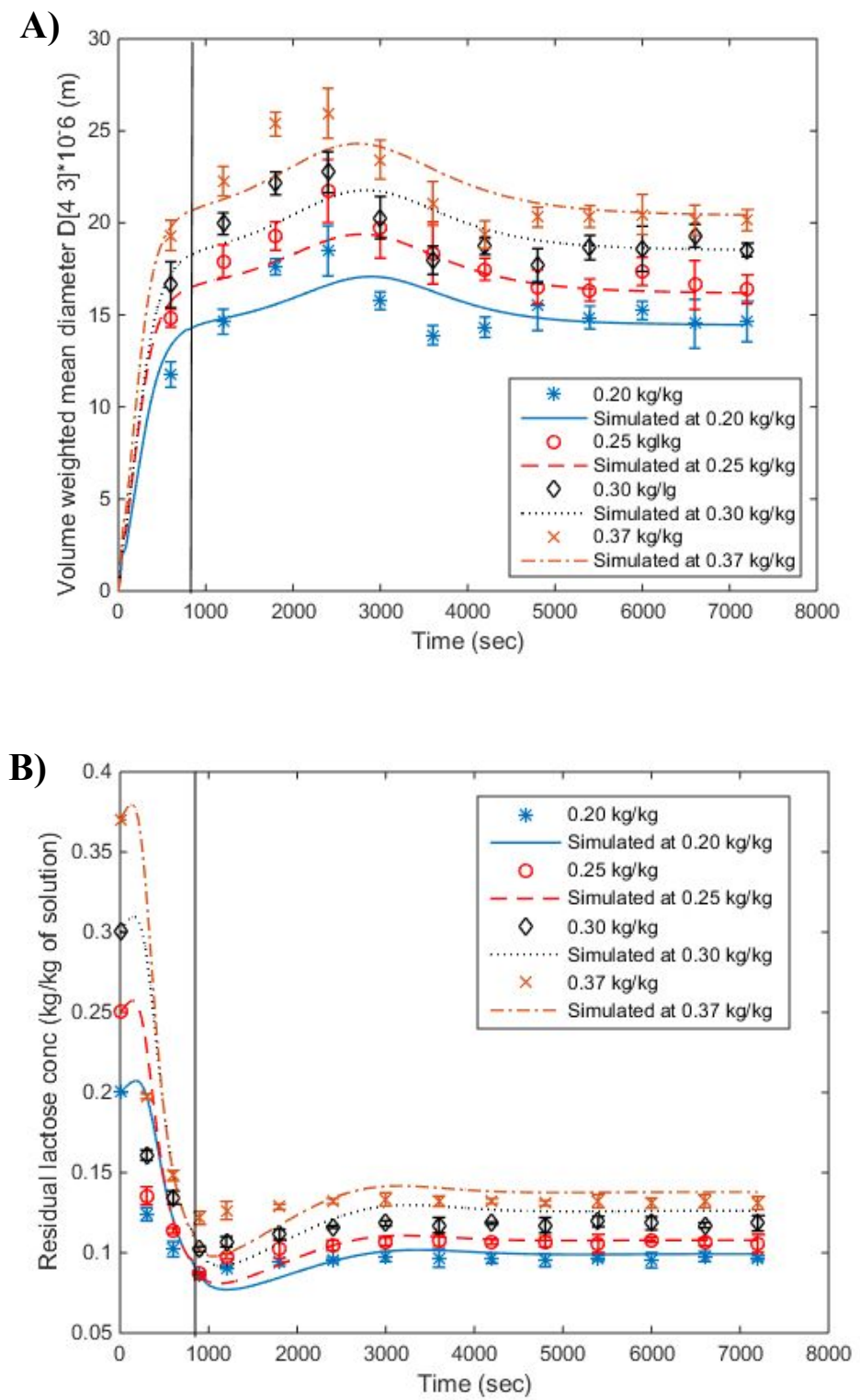
Figure S13. (A) Average crystal size and (B) Residual lactose concentration profile for a) 0.20 b) 0.25 c) 0.30 d) $0.37 \mathrm{~kg} / \mathrm{kg}$ of lactose solution. For all trials, feed rate for both lactose solution and ethanol was $0.25 \mathrm{~mL} / \mathrm{s}$ and residence time was $\tau=900 \mathrm{~s}$. The transition from semi-batch to continuous mode is represented by a vertical line at $900 \mathrm{~s}$.

\section{Effect of residence time}

Average crystal size and residual lactose recovery for different residence time is shown in Figure S14.

A)
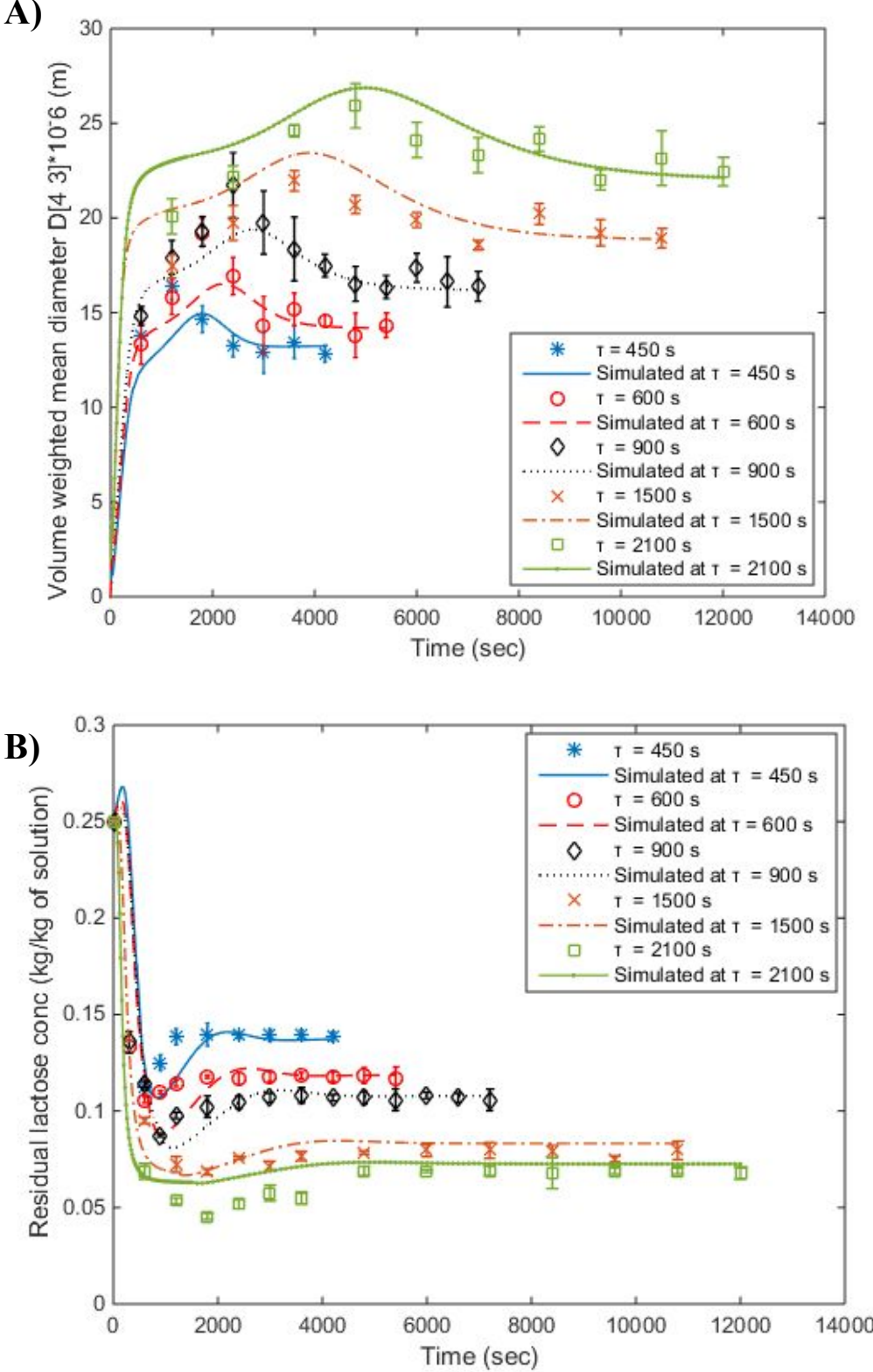
Figure S14. (A) Average crystal size and (B) Residual lactose profile for different residence times. The initial lactose concentration was $0.25 \mathrm{~kg} / \mathrm{kg}$. Ratio of addition rate antisolvent to lactose solution was maintained as 1:1 for all residence times.

\section{Effect of impurities}

Average crystal size and residual lactose recovery for $0.1,0.25$ and $0.5 \%$ WPC is shown in Figure S15.

A)

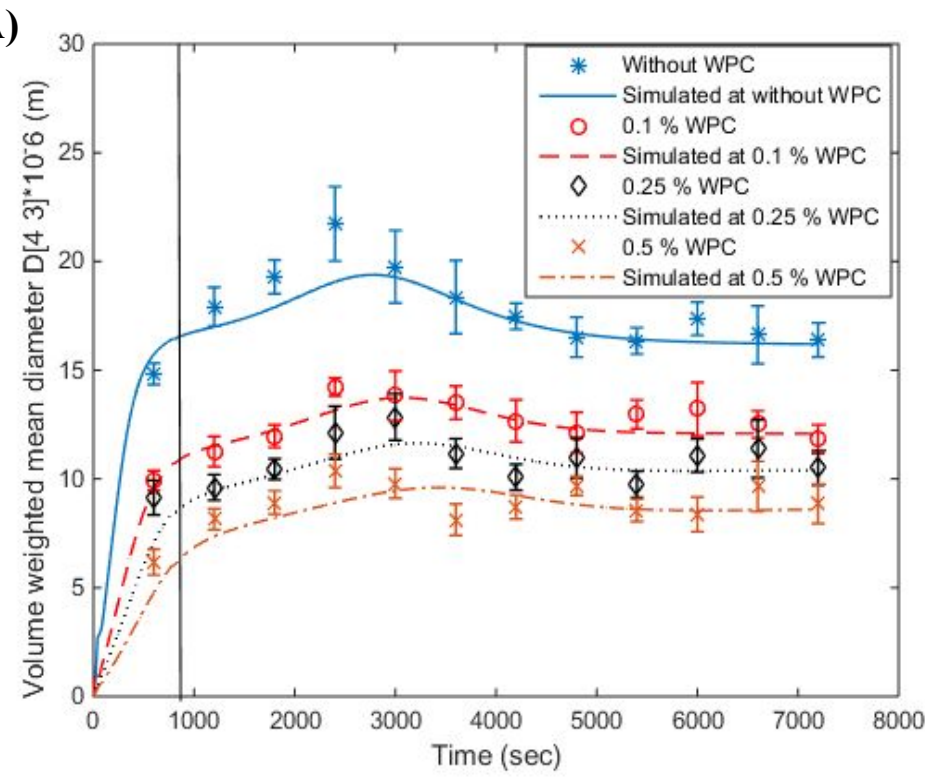

B)

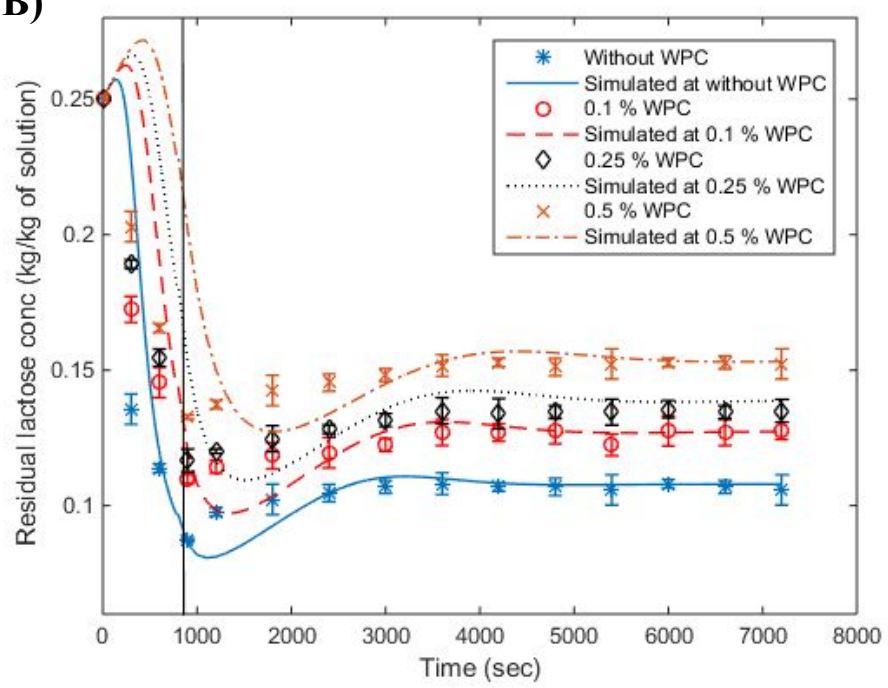


Figure S15. (A) Average particle size and (B) Residual lactose profile for $0.1,0.25$ and 0.5 $\%$ of whey protein concentrations. The initial lactose concentration was $0.25 \mathrm{~kg} / \mathrm{kg}$. The flow rate was $0.25 \mathrm{~mL} / \mathrm{s}$ for both lactose and ethanol solution and residence time was $\tau=900 \mathrm{~s}$. Transition from semi-batch to continuous mode is represented by a vertical line.

\section{Effect of recycle}

Average crystal size, residual lactose recovery and impact of different recycle ratio on crystal size (with and without fines) are shown in Figure S16.

A)

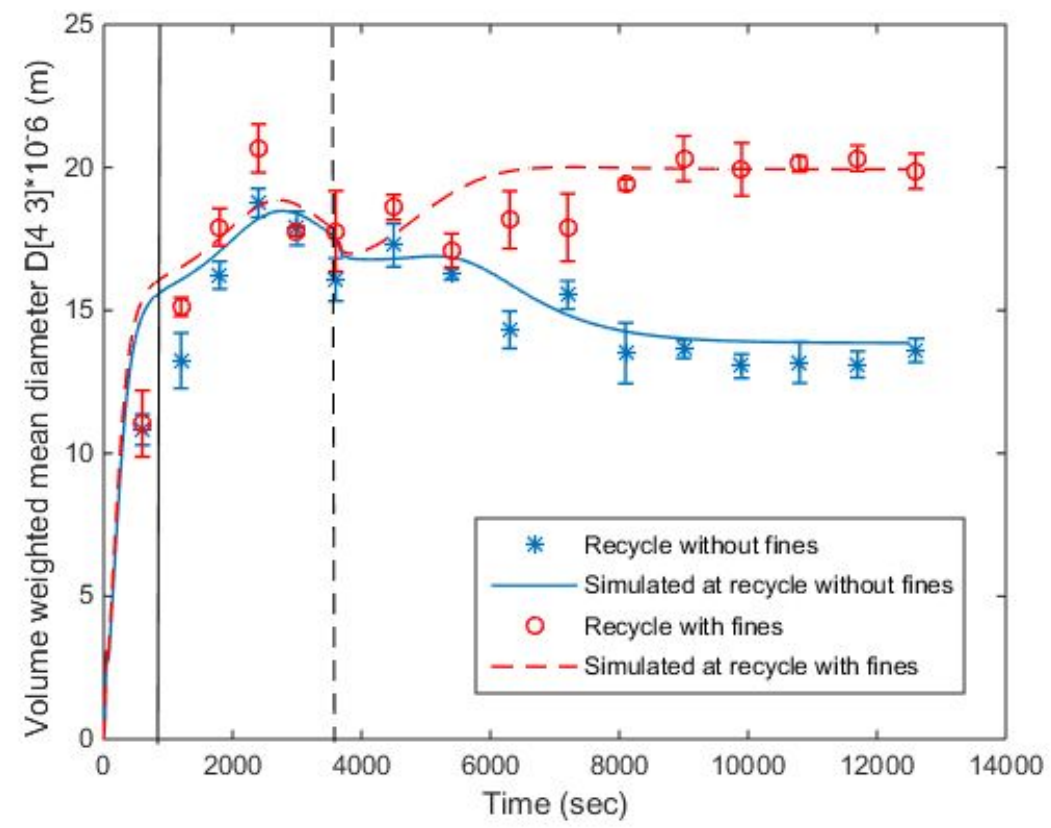



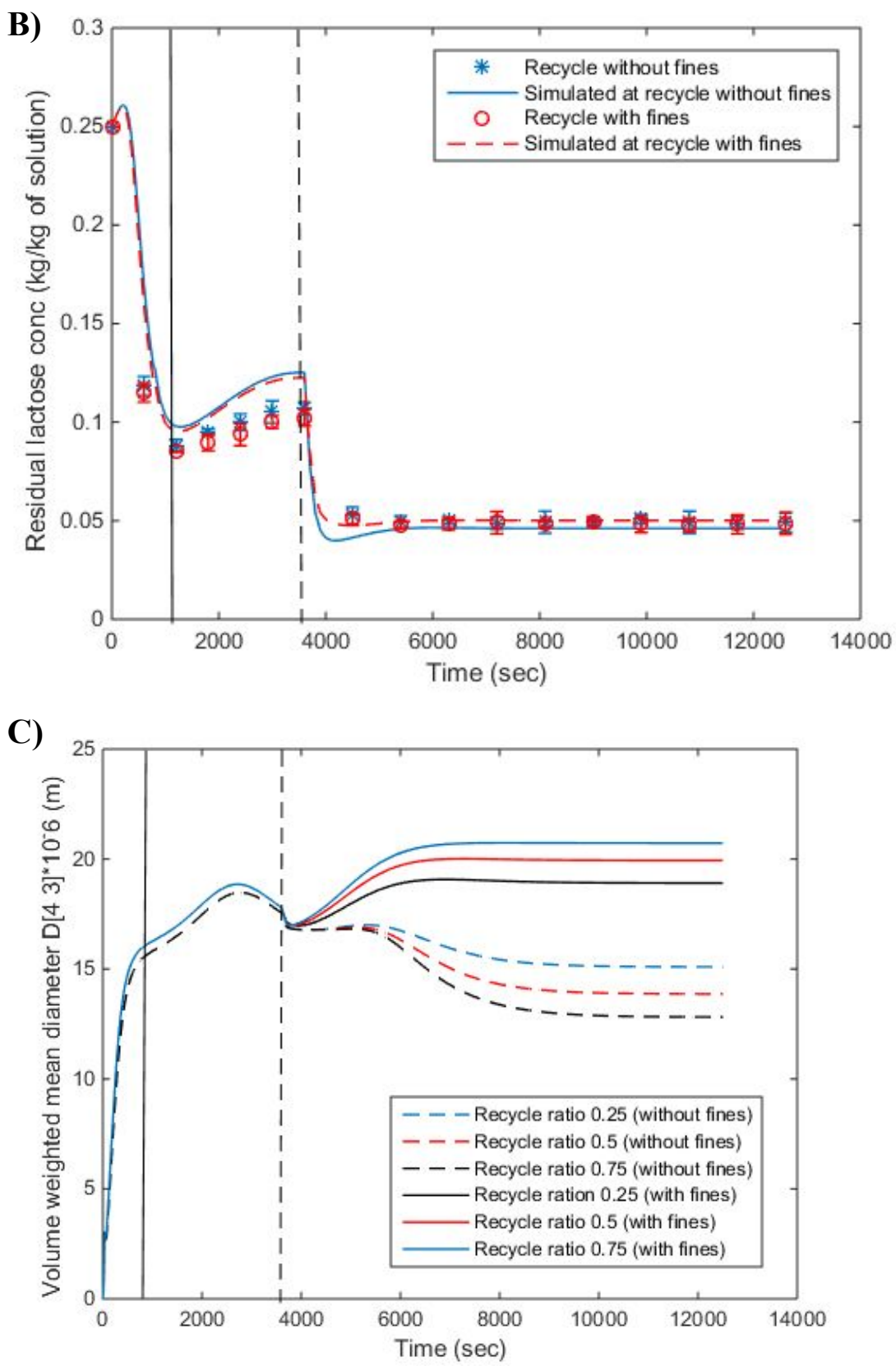

Figure S16. (A) The average particle size (B) Residual lactose concentration profile for recycling of solution without fines and with fines recycle. Recycle feed flow rate $0.25 \mathrm{~mL} / \mathrm{s}$ $($ Recycle ratio $=0.5)$ The flow rate was $0.125 \mathrm{~mL} / \mathrm{s}$ for both lactose solution and antisolvent. (C) The simulated average particle size profile for different recycle ratio i.e. with fines (solid lines) and without fines (dotted lines).Initial lactose concentration was $0.25 \mathrm{~kg} / \mathrm{kg}$. For all trials, Antisolvent: Lactose solution ratio was 1:1. Transition from semi-batch to continuous 
mode and start-up of recycle stream are represented by solid and dashed vertical lines at 900 and $3600 \mathrm{~s}$, respectively.

Once the developed model was correctly able to predict the experimental trends, further simulations at different recycle ratios were carried out to understand the impact of recycle as illustrated in Figure 16(C). As recycle ratio increased i.e. volume of recycle stream increases, the steady state crystal size distribution increased for recycle with fines, however opposite trends were observed for recycle without fines.

\section{$\underline{\text { SUPPLEMENTARY INFORMATION (S5) }}$}

\section{Kinetic Parameter Estimation}

The values of nucleation and growth coefficient obtained using data fitting carried out for each trial are reported in Table S2.

Table S2. Estimated kinetic parameters for antisolvent crystallization of lactose at different operating parameters

\begin{tabular}{ccc}
\hline Initial lactose concentration & $\mathbf{k}_{\mathbf{g}}$ & $\mathbf{k}_{\mathbf{b}}$ \\
\hline $0.20 \mathrm{~kg} / \mathrm{kg}$ & $3.13 \times 10^{-6}$ & $2.51 \times 10^{8}$ \\
$0.25 \mathrm{~kg} / \mathrm{kg}$ & $2.52 \times 10^{-6}$ & $2.46 \times 10^{8}$ \\
$0.30 \mathrm{~kg} / \mathrm{kg}$ & $1.76 \times 10^{-6}$ & $2.13 \times 10^{8}$ \\
$0.37 \mathrm{~kg} / \mathrm{kg}$ & $1.24 \times 10^{-6}$ & $2.07 \times 10^{8}$ \\
Average & $\mathbf{2 . 1 6} \pm \mathbf{0 . 8 3} \times \mathbf{1 0}^{-\mathbf{6}}$ & $\mathbf{2 . 2 9} \pm \mathbf{0 . 2 3} \times \mathbf{1 0}^{\mathbf{8}}$ \\
& & \\
Residence time & & $7.53 \times 10^{8}$ \\
$450 \mathrm{~s}$ & $1.73 \times 10^{-6}$ & $4.51 \times 10^{8}$ \\
$600 \mathrm{~s}$ & $2.12 \times 10^{-6}$ & $2.46 \times 10^{8}$ \\
$900 \mathrm{~s}$ & $2.52 \times 10^{-6}$ & $7.56 \times 10^{8}$ \\
$1500 \mathrm{~s}$ & $5.15 \times 10^{-6}$ & $4.13 \times 10^{8}$ \\
$2100 \mathrm{~s}$ & $6.52 \times 10^{-6}$ & $\mathbf{5 . 2 4} \pm \mathbf{2 . 2 2} \times \mathbf{1 0}^{8}$ \\
Average & $\mathbf{3 . 6 1} \pm \mathbf{2 . 1 1} \times \mathbf{1 0}^{-\mathbf{6}}$ & \\
& & $5.02 \times 10^{8}$ \\
Whey protein concentration & & $7.14 \times 10^{8}$ \\
$0.1 \% \mathrm{WPC}$ & $1.10 \times 10^{-6}$ & $1.15 \times 10^{8}$ \\
$0.25 \% \mathrm{WPC}$ & $7.53 \times 10^{-7}$ & $\mathbf{4 . 4 3} \pm \mathbf{2 . 1 2} \times \mathbf{1 0}^{\mathbf{8}}$ \\
$0.5 \% \mathrm{WPC}$ & $4.71 \times 10^{-7}$ & \\
Average & $\mathbf{7 . 7 5} \pm \mathbf{3 . 1 5} \times \mathbf{1 0}^{-7}$ & \\
Recycle & &
\end{tabular}




\section{NOMENCLATURE}

B : Rate of primary nucleation (\#/s (kg of slurry))

$\mathrm{G}:$ Growth rate $(\mathrm{m} / \mathrm{s})$

b : Nucleation order

g : Growth order

$\mathrm{k}_{\mathrm{b}}$ : Nucleation coefficient (\#/s ( $\mathrm{kg}$ of slurry))((kg of lactose) $/(\mathrm{kg}$ of solution $\left.)\right)^{-\mathrm{b}}$

$\mathrm{k}_{\mathrm{g}}$ : Growth coefficient $(\mathrm{m} / \mathrm{s})((\mathrm{kg} \text { of lactose }) /(\mathrm{kg} \text { of solution }))^{-\mathrm{g}}$

$\mathrm{n}(\mathrm{L})$ : Population density of crystals size ([\#/(kg of slurry $)(\mathrm{m})])$

$\tau:$ Residence time (s)

L : Crystal size (m)

$\mathrm{M}$ : Slurry mass present in the crystallizer $(\mathrm{kg})$

$\mathrm{D}[4$ 3] : Volume weighted mean diameter (m)

$\mathrm{C}:$ Lactose (solute) concentration ( $\mathrm{kg} / \mathrm{kg}$ of solution)

$\mathrm{C}_{\mathrm{f}}$ : Lactose (solute) concentration present in the feed solution $(\mathrm{kg} / \mathrm{kg}$ of solution)

$\mathrm{C}_{\mathrm{e}}$ : Saturation concentration of solute $(\mathrm{kg} / \mathrm{kg}$ of solution $)$

$\mathrm{C}_{\alpha}: \alpha$-Lactose monohydrate concentration $(\mathrm{kg} / \mathrm{kg}$ of solution)

$\mathrm{C}_{\alpha \mathrm{e}}$ : saturation concentration of $\alpha$-Lactose monohydrate ( $\mathrm{kg} / \mathrm{kg}$ of solution)

$\mathrm{C}_{\beta}: \beta$-Lactose concentration $(\mathrm{kg} / \mathrm{kg}$ of solution) 
$\mathrm{C}_{\mathrm{c}}$ : Crystal content of slurry ( $\mathrm{kg} /(\mathrm{kg}$ of slurry))

$\mathrm{C}_{\mathrm{t}}$ : Lactose (solute) concentration present in the collection tank $(\mathrm{kg} / \mathrm{kg}$ of solution)

$\varphi$ : Voidage ((kg of solution)/ (kg of slurry))

1- $\varphi$ : Crystal content of slurry ((kg of crystalline lactose) /(kg of slurry))

$\varphi_{\mathrm{r}}:$ Voidage of recycle stream $((\mathrm{kg}$ of solution $) /(\mathrm{kg}$ of slurry $))$

$\varphi_{\mathrm{t}}$ : Voidage of solution leaving the tank ((kg of solution) $/(\mathrm{kg}$ of slurry $\left.)\right)$

$\mathrm{x}$ : Antisolvent fraction ( $\mathrm{kg}$ of ethanol $/ \mathrm{kg}$ of slurry)

$\mathrm{t}$ : Crystallization time $(\mathrm{s})$

$\rho_{c}:$ Density of lactose crystal $\left(\mathrm{kg} / \mathrm{m}^{3}\right)$

$\rho_{s}:$ Density of solution $\left(\mathrm{kg} / \mathrm{m}^{3}\right)$

$\rho_{f}:$ Density of lactose (feed) solution $\left(\mathrm{kg} / \mathrm{m}^{3}\right)$

$\rho_{e}:$ Density of antisolvent $\left(\mathrm{kg} / \mathrm{m}^{3}\right)$

$\rho_{r}$ : Density of recycle stream $\left(\mathrm{kg} / \mathrm{m}^{3}\right)$

$\rho_{t}$ : Density of solution leaving the tank $\left(\mathrm{kg} / \mathrm{m}^{3}\right)$

$\rho_{e q}$ : Density of solution at equilibrium $\left(\mathrm{kg} / \mathrm{m}^{3}\right)$

$M W_{\alpha L}:$ Molecular weight of $\alpha$-Lactose

$M W_{\alpha L H}:$ Molecular weight of $\alpha$-Lactose monohydrate

$Q_{e}:$ Volumetric flow rate of antisolvent $\left(\mathrm{m}^{3} / \mathrm{s}\right)$

$Q_{f}$ : Volumetric flow rate of feed $\left(\mathrm{m}^{3} / \mathrm{s}\right)$

$Q_{o}$ : Flow rate of outlet solution $\left(\mathrm{m}^{3} / \mathrm{s}\right)$

$Q_{r}:$ Flow rate of recycle stream $\left(\mathrm{m}^{3} / \mathrm{s}\right)$

$Q_{\text {out }}$ : Flow rate of solution leaving the collection tank $\left(\mathrm{m}^{3} / \mathrm{s}\right)$

$K_{m}:$ Mutarotation rate constant

$T S$ : Total solids of the slurry

$F$ : Temperature dependent correction factor 
$m_{0}$ : Zeroth moment of Crystal size distribution (\#/ (kg of slurry))

$m_{1}$ : First moment of Crystal size distribution ( $\mathrm{m} /(\mathrm{kg}$ of slurry))

$m_{2}$ : Second moment of Crystal size distribution ( $\mathrm{m}^{2} /(\mathrm{kg}$ of slurry))

$m_{3}$ : Third moment of Crystal size distribution $\left(\mathrm{m}^{3} /(\mathrm{kg}\right.$ of slurry))

$m_{4}$ : Fourth moment of Crystal size distribution ( $\mathrm{m}^{4} /(\mathrm{kg}$ of slurry $\left.)\right)$

\section{REFERENCES}

(1) MacFhionnghaile, P.; Svoboda, V.; McGinty, J.; Nordon, A.; Sefcik, J. Crystallization Diagram for Antisolvent Crystallization of Lactose: Using Design of Experiments to Investigate Continuous Mixing-Induced Supersaturation. Cryst. Growth Des. 2017, 17, $2611-2621$.

(2) Ramisetty, K. A.; Pandit, A. B.; Gogate, P. R. Ultrasound-Assisted Antisolvent Crystallization of Benzoic Acid: Effect of Process Variables Supported by Theoretical Simulations. Ind. Eng. Chem. Res. 2013, 52, 17573-17582.

(3) Randolph, A. D.; Larson, M. A. Theory of ParticulateProcesses, Academic Press, San Diego. 1988.

(4) Agrawal, S.; Tony, A.; Mcleod, J.; Jones, J.; Bronlund, J. Mathematical Modelling and Analysis of an Industrial Scale Evaporative Crystallizer Producing Lactose Monohydrate. J. Food Eng. 2015, 154, 49-57

(5) Subramanian, R. Flow through Packed Beds and Fluidized Beds, 2001.

(6) Agrawal, S.; Paterson, T.; Jones, J.; McLeod, J.; Bronlund, J. A Mathematical Model Based Parametric Sensitivity Analysis of an Evaporative Crystallizer for Lactose Monohydrate. Food Bioprod. Process. 2016, 97, 1-11. 
(7) Mcleod, J. Nucleation and Growth of Alpha Lactose Monohydrate, Ph.D. Thesis, Massey University, Manawatu, New Zealand, 2007.

(8) Machado, J. J. B.; Coutinho, J. A.; Macedo, E. A. Solid - Liquid Equilibrium of $\alpha-$ Lactose in Ethanol / Water. Fluid Phase Equilib. 2000, 173, 121-134.

(9) Agrawal, S. Evaporative Crystallization of $\alpha$-Lactose Monohydrate, Ph.D. Thesis, Massey University, Manawatu, New Zealand, 2012. 